\title{
Tissue-specific regulation of thyroid hormone receptor mRNA isoforms and target gene proteins in domestic ducks
}

\author{
C M Bishop ${ }^{1,3}$, C J McCabe ${ }^{2}$, N J L Gittoes ${ }^{2}$, P J Butler ${ }^{1}$ and \\ J A Franklyn ${ }^{2}$ \\ ${ }^{1}$ School of Biosciences, University of Birmingham, Edgbaston, Birmingham B15 2TT, UK \\ ${ }^{2}$ Department of Medicine, University of Birmingham, Queen Elizabeth Hospital, Edgbaston, Birmingham B15 2TH, UK \\ ${ }^{3}$ School of Biological Sciences, University of Wales, Bangor, Gwynedd LL57 2UW, UK \\ (Requests for offprints should be addressed to C M Bishop at School of Biological Sciences, University of Wales, Bangor, Gwynedd LL57 2UW, UK; \\ Email: c.bishop@bangor.ac.uk)
}

\begin{abstract}
Skeletal muscles are important target tissues for thyroid hormone action. The present study examines the influence of thyroid status on muscle growth and tissue-specific expression of thyroid receptor (TR) mRNA isoforms in a commercial strain of the domestic duck (Anas platyrhynchos). Four groups $(n=5)$ of 1 -week-old ducklings were rendered either hypothyroid by treatment with methimazole $\left(6 \mathrm{mg} 100 \mathrm{~g}^{-1}\right.$ body mass or $12 \mathrm{mg} 100 \mathrm{~g}^{-1}$ body mass), or hyperthyroid by treatment with methimazole (6 mg $100 \mathrm{~g}^{-1}$ body mass) in combination with thyroid hormones $\left(5 \mu \mathrm{g}\right.$ thyroxine $\left(\mathrm{T}_{4}\right)$ and tri-iodothyronine $\left(\mathrm{T}_{3}\right)$ $100 \mathrm{~g}^{-1}$ body mass or $10 \mu \mathrm{g} \mathrm{T}_{4}$ and $\mathrm{T}_{3} 100 \mathrm{~g}^{-1}$ body mass). Serum and tissue samples (cardiac, pectoralis and semimembranosus leg muscle, liver, pituitary and cerebral cortex) were collected from these four groups, and from a group of untreated controls, at 8 weeks of age. Development of duckling morphology was retarded in methimazole-treated birds compared with that in euthyroid controls, as evidenced by differences in skeletal dimensions, primary feather length, and body and muscle masses. Body mass was lower by $18 \%$, and relative masses
\end{abstract}

of cardiac and pectoralis muscles were lower by $28 \%$ and $32 \%$ respectively. Heterologous oligonucleotides for TR $\alpha$, TR $\beta 0$, TR $\beta 2$ and the housekeeping gene $\beta$-actin were derived from chicken sequences. RT-PCR showed that TR $\alpha$ mRNA was expressed in all tissues but was not significantly affected by any of the experimental treatments. TR $\beta 0$ mRNA expression was significantly lower in the leg muscles of ducklings treated with $12 \mathrm{mg}$ methimazole $100 \mathrm{~g}^{-1}$ body mass $(0 \cdot 109 \pm 0.047$ TR: $\beta$ actin ratio, $P<0.05)$ compared with that in euthyroid controls $(0 \cdot 380 \pm 0 \cdot 202)$, but was unaltered in the pectoralis and cardiac muscles. Expression of TR $\beta 0 \mathrm{mRNA}$ was significantly higher in pectoralis (by $3 \cdot 5$-fold, $P<0.05$ ), cardiac (by $4 \cdot 2$-fold, $P=0.003$ ) and leg (by 4.0-fold, $P<0 \cdot 001)$ muscles of ducklings treated with thyroid hormones compared with those in euthyroid controls $(0 \cdot 098 \pm 0 \cdot 019,0 \cdot 822 \pm 0 \cdot 297$ and $0 \cdot 38 \pm 0 \cdot 202$ TR: $\beta$-actin respectively). Only the pituitary gland expressed significant levels of TR $\beta 2$ mRNA.

Journal of Endocrinology (2000) 165, 607-615

\section{Introduction}

Thyroid hormones influence a large number of biological functions by modulating gene expression (Lazar 1993), and are essential for the normal development of brain (Dussault \& Ruel 1987, Oppenheimer \& Schwartz 1997) and muscle tissues (Everts 1996, Harrison et al. 1996) during ontogeny. Many species of wildfowl (ducks and geese) are migratory and their young undergo rapid growth during development in preparation for their first long distance flights (Sedinger 1986, Bishop et al. 1995). However, the locomotor and cardiac muscles of wildfowl show tissuespecific rates of maturation and different patterns of growth (Bishop et al. 1996), reflecting their various functional requirements during development. In particular, the main flight muscles (the pectoralis) show an exponential increase in mass between 1 and 7 weeks of age, when the juveniles first begin to fly. In barnacle geese (Branta leucopsis), this rapid development of the pectoralis muscles occurs in parallel with an increase in circulating levels of thyroid hormone (Bishop et al. 1998).

Skeletal muscles are an important target tissue for thyroid hormones and, in birds, thyroid hormone deficiency has been shown to affect the mass of the developing locomotor muscles, and the maximum activities of muscle mitochondrial enzymes such as citrate synthase (CS) involved in oxidative phosphorylation of fuel substrates (Deaton et al. 1997, 1998). Hypothyroidism 
in goslings from 2 to 7 weeks of age resulted in a significantly lower mass of the pectoralis and cardiac ventricle muscles (while the mass of the legs was not affected), and a lower activity of CS in the pectoralis and leg muscles, while the heart was not affected (Deaton et al. 1997, 1998). These results are consistent with the hypothesis that the muscle-specific responses of wildfowl to altered thyroid status may reflect differential expression of thyroid receptor (TR) mRNA, leading to altered expression, or function, of nuclear TR isoforms in target muscles.

The liver is also an important target tissue for thyroid hormones and a direct relationship between changes in thyroid status and the activity of the lipogenic enzymes of the liver (e.g. malate dehydrogenase and malic enzyme) has been reported in the rat (Diamant et al. 1972), and activation of the thyroid response elements for the malic enzyme gene has been studied in vitro (Petty et al. 1990, Hodnett et al. 1996). However, very little is known about TR isoform developmental expression in birds (Forrest et al. 1990, Sjöberg et al. 1992, Muñoz \& Bernal 1997).

In chickens, the product of the TR $\alpha$ gene is a single TR $\alpha$ mRNA which is translated into two proteins by the use of two alternative start codons (Forrest et al. 1991). The TR $\beta$ gene gives rise to two variant mRNAs which have been designated TR $\beta 0$ and TR $\beta 2$ (Sjöberg et al. 1992, Muñoz \& Bernal 1997). TR $\beta 0$ is probably homologous to TR $\beta 1$ but the protein has a short amino terminal sequence (Sjöberg et al. 1992). In the present study, we have used a commercial strain of the domestic duck (Anas platyrhynchos), which has been selectively bred over hundreds of years from the wild mallard (Horton 1928). We developed a method for quantifying relative differences in avian TR $\alpha$ and TR $\beta$ mRNA isoform expression by RT-PCR (Gittoes et al. 1997, 1998), and examined the effect of changes in thyroid status on tissue-specific pretranslational expression of TR isoforms.

\section{Materials and Methods}

\section{Animals}

Twenty-five 1-day-old Pekin ducklings were provided by a commercial supplier and kept indoors with food (chick starter crumbs) and water provided ad libitum, with a photoperiod of $18 \mathrm{~h}$ light: $6 \mathrm{~h}$ darkness. Experimental treatments began at 1 week of age and were conducted in accordance with humane practice as specified by the Animal (Scientific Procedures) Act 1986 of the UK.

\section{Treatment groups and protocol}

At 1 week of age, ducklings were allocated at random into five groups of five. All birds between the ages of 1 and 8 weeks of age received daily treatment during the morning, by oral gavage, of the following mixtures. Two groups were made hypothyroid by treatment with methimazole at $6 \mathrm{mg}$ or $12 \mathrm{mg} 100 \mathrm{~g}^{-1}$ body mass (BM) respectively. Two further groups were both treated with methimazole at $6 \mathrm{mg} 100 \mathrm{~g}^{-1} \mathrm{BM}$ and made hyperthyroid by the addition of $5 \mu \mathrm{g}$ thyroxine $\left(\mathrm{T}_{4}\right) \mathrm{g}^{-1} \mathrm{BM}$ and $5 \mu \mathrm{g}$ triiodothyronine $\left(\mathrm{T}_{3}\right) \mathrm{g}^{-1} \mathrm{BM}$, or $10 \mu \mathrm{g} \mathrm{T}_{4} \mathrm{~g}^{-1} \mathrm{BM}$ and $10 \mu \mathrm{g} \mathrm{T} \mathrm{T}_{3}$ respectively. The concentrations of methimazole and $\mathrm{T}_{4}$ and $\mathrm{T}_{3}$ used in this experiment were partially based on earlier work on barnacle geese (Deaton et al. 1997, 1998). Two doses were used due to uncertainties in anticipating species-specific differences in the response to methimazole and $\mathrm{T}_{4} / \mathrm{T}_{3}$ treatment, and to provide preliminary information with regard to possible quantitative effects of these treatments. One group comprised control birds that were orally dosed with a carrier solution. The methimazole and thyroid hormone solutions were made up twice a week, using a dilute ammonia solution as a carrier. The carrier solution consisted of $5 \mathrm{ml} \mathrm{35 \%}$ ammonia mixed with $5 \mathrm{ml}$ water to which was added $20 \mathrm{ml}$ sterile saline solution followed by $1 \mathrm{~g}$ bovine serum albumin (BSA). Once the BSA was dissolved the hormones were added and the $\mathrm{pH}$ lowered very gradually to $\mathrm{pH} 7 \cdot 4$. Finally, additional sterile saline was added to the mixture to a final volume of $50 \mathrm{ml}$.

\section{Sample collection}

At 8 weeks of age, the birds were given a final treatment dose around $0800 \mathrm{~h}$, and a $1 \mathrm{ml}$ serum sample was then collected from a peripheral leg vein $4 \mathrm{~h}$ later and frozen at $-20{ }^{\circ} \mathrm{C}$. The birds were then killed by intravenous injection of pentobarbitone, followed by immediate dissection, and $500 \mathrm{mg}$ samples taken from the cardiac, pectoralis and semimembranosus muscles (Bishop et al. 1995, Deaton et al. 1996), and from the liver, pituitary and cerebral cortex for storage in liquid nitrogen until further analysis. Various morphometric measurements were made during dissection, including the total mass of the semimembranosus, pectoralis and cardiac muscles, and the total length of the sternum, tibiotarsus and radius bones and the length of the 9th primary feather of the wing. Serum $T_{4}$ and $\mathrm{T}_{3}$ were assayed at Leicester Royal Infirmary using an established commercial radioimmunoassay.

\section{Analysis of maximum enzyme activities}

Muscle samples were homogenised on the day of assay in 9 volumes (wet weight) of ice-cold extraction buffer: $50 \mathrm{mM}$ imidazole, $1 \mathrm{mM}$ EGTA, $2 \mathrm{mM} \mathrm{MgCl}$, $250 \mathrm{mM}$ mannitol, $\mathrm{pH} 7 \cdot 4$. Homogenisation was at 13500 r.p.m. for $15 \mathrm{~s}$ and repeated following a 2-min interval, using an Ultra-Turrax homogenizer with a $10 \mathrm{~N}$ shaft. Homogenate $(300 \mu \mathrm{l})$ was then aliquoted into microcentrifuge tubes and $30 \mu \mathrm{l}$ of a $10 \%$ Triton solution were added, followed by gentle mixing, to give an 11-fold final dilution $(\mathrm{w} / \mathrm{v})$. 
Table 1 Fluorescence intensity (arbitrary units) of $\beta$-actin mRNA product following RT-PCR and separation on a $2 \%$ agarose gel, showing that there was no systematic or significant difference between treatments within tisues. Data are presented as means \pm S.E.M.

\begin{tabular}{|c|c|c|c|}
\hline & $\begin{array}{l}\text { Pectoralis } \\
\text { muscle }\end{array}$ & $\begin{array}{l}\text { Cardiac } \\
\text { muscle }\end{array}$ & $\begin{array}{l}\text { Semimembranosus } \\
\text { muscle }\end{array}$ \\
\hline \multicolumn{4}{|l|}{ Treatment } \\
\hline Control & $463 \cdot 0 \pm 66 \cdot 3$ & $276 \cdot 3 \pm 87 \cdot 3$ & $340 \cdot 3 \pm 94 \cdot 1$ \\
\hline MMZ (12 mg) & $501 \cdot 8 \pm 99 \cdot 0$ & $286 \cdot 1 \pm 59 \cdot 8$ & $284 \cdot 3 \pm 66 \cdot 9$ \\
\hline MMZ (6 mg) & $537 \cdot 4 \pm 143 \cdot 2$ & $172 \cdot 2 \pm 35 \cdot 1$ & $303 \cdot 5 \pm 146 \cdot 3$ \\
\hline $\mathrm{MMZ}+\mathrm{T}_{4} / \mathrm{T}_{3}(5 \mu \mathrm{g})$ & $471 \cdot 8 \pm 25 \cdot 7$ & $272 \cdot 5 \pm 54 \cdot 6$ & $194 \cdot 3 \pm 72 \cdot 7$ \\
\hline $\mathrm{MMZ}+\mathrm{T}_{4} / \mathrm{T}_{3}(10 \mu \mathrm{g})$ & $494 \cdot 7 \pm 64 \cdot 0$ & $303 \cdot 1 \pm 89 \cdot 0$ & $294 \cdot 8 \pm 56 \cdot 7$ \\
\hline ANOVA & $F=0 \cdot 1, P>0 \cdot 9$ & $F=0.4, P>0.8$ & $F=0.9, P>0.5$ \\
\hline
\end{tabular}

MMZ, methimazole.

Assay solutions were prepared on the day of assay and held at $41{ }^{\circ} \mathrm{C}$ in a water bath. Samples were assayed for CS (EC $4 \cdot 1 \cdot 3 \cdot 7$ ) activity in the following solution: $0.5 \mathrm{mM}$ oxaloacetate (omitted from control cuvette), $0.25 \mathrm{mM}$ 5, $5^{\prime}$-dithiobis(2-nitrobenzoic acid), $0 \cdot 3 \mathrm{mM}$ acetyl-CoA in $50 \mathrm{mM}$ triethanolamine- $\mathrm{HCl}, \mathrm{pH} 8 \cdot 0$, and changes in spectral absorbence were read at $412 \mathrm{~nm}$ using a micromole extinction coefficient of $13 \cdot 6$ (Bishop et al. 1995). Malic enzyme (EC $1 \cdot 1 \cdot 1 \cdot 40$ ) activity was assayed in the following solution: $0.5 \mathrm{mM}$ malate (omitted from control cuvette), $0.4 \mathrm{mM} \mathrm{NADP}{ }^{+}, 4 \mathrm{mM} \mathrm{MgCl}_{2}, 0.3 \mathrm{mM}$ dithiothreitol in $50 \mathrm{mM}$ imidazole, $\mathrm{pH} 7 \cdot 4$, and changes in spectral absorbence were read at $340 \mathrm{~nm}$ using a micromole extinction coefficient of $6 \cdot 22$. Changes in spectral absorbence were measured with a Shimadzu UV - 160A ultraviolet-visible recording spectrophotometer fitted with a CPS-240 cell positioner and temperature control set to $41{ }^{\circ} \mathrm{C}$. Volumes of assay solution in the cuvette were $1 \mathrm{ml}$ with addition of $5 \mu \mathrm{l}$ aliquots of the crude homogenate. Samples were homogenised in batches of six at a time, placed on ice, and assayed immediately.

\section{RNA extraction}

Frozen samples of pectoralis, semimembranosus and cardiac muscle were ground to a fine powder in liquid nitrogen using a cold pestle and mortar, and the powder returned to storage in cryovials kept in liquid nitrogen until required. Total RNA was isolated from freshly thawed tissue using a commercially available kit (Trireagent; Sigma Co., Poole, Dorset, UK), based on the guanidinium phenol-chloroform extraction technique. Approximately $100 \mathrm{mg}$ tissue, or powder, were homogenised in an Ultraturax homogeniser with a $10 \mathrm{~N}$ shaft at 8000 r.p.m. for $30 \mathrm{~s}$, in the presence of $2 \mathrm{ml}$ Tri-reagent. Total RNA was extracted by following the manufacturer's protocol.

\section{Quantification of relative differences in $m R N A$ by $R T-P C R$}

RT-PCR and the method of cDNA quantification were based on methods previously described by Gittoes et al.
(1997, 1998). Reverse transcription was performed using a commercially available kit (Promega, Southampton, Hants, UK). Total RNA (2 $\mu \mathrm{g})$ was added to $60 \mathrm{pmol}$ oligo $(\mathrm{dT})_{15}$ primer and the volume adjusted to $32 \mu \mathrm{l}$ with water. Primer annealing was encouraged by incubation of the solution for $10 \mathrm{~min}$ at $77^{\circ} \mathrm{C}$, and the mixture cooled to room temperature. Ten microlitres of $5 \times$ avian myeloblastosis virus (AMV) reverse transcriptase buffer, $5 \mu \mathrm{l}$ dNTP mix (20 $\mu$ mol each), 50 units RNAsin and 15 units AMV reverse transcriptase were added, followed by incubation for $60 \mathrm{~min}$ at $42{ }^{\circ} \mathrm{C}$. The $\mathrm{RT}$ reaction was terminated by heating to $90{ }^{\circ} \mathrm{C}$ for $5 \mathrm{~min}$.

PCR was carried out in a total volume of $50 \mu \mathrm{l}$ and all samples underwent PCR at the same time in the same experiment. Each PCR tube contained 60 pmol each of forward and reverse primers (see Table 1), $1 \mu \mathrm{l}$ dNTP mix (20 $\mu \mathrm{mol}$ each), $2-3 \mu \mathrm{mol} \mathrm{Mg}^{2+}$ and $2-10 \%$ of the RT cDNA reaction product. Mineral oil was placed over the reaction mixture which was pulse centrifuged, heated to $95^{\circ} \mathrm{C}$ for $6 \mathrm{~min}$, cooled to $72{ }^{\circ} \mathrm{C}$ and the Taq polymerase added. PCR cycling was commenced using a melt temperature of $95{ }^{\circ} \mathrm{C}$ and extension at $72{ }^{\circ} \mathrm{C}$. PCR products were visualised on $2 \%$ TBE agarose gels stained with ethidium bromide. PCR conditions for temperature and $\mathrm{Mg}^{2+}$ concentration were optimised for each primer pair and comparative kinetic analyses performed to determine that the selected PCR cycle number for each primer pair was within the exponential phase of product generation. PCR reactions and subsequent gel analysis were performed in duplicate. Ethidium bromide-stained 2\% agarose gels were photographed under u.v. light, digitised and densitometry performed on the product bands. Quantitation of RT-PCR by analysis of ethidium-stained gels has yielded consistent and significant results in previous studies (Gittoes et al. 1997, 1998) and was sufficiently sensitive to provide quantifiable results in the present study.

\section{Oligonucleotide primer design and PCR product sequencing}

Oligonucleotide primer design was carried out on GCG-8 and DNAstar software, using chicken sequences for TR $\alpha$ 
Table 2 Oligonucleotide sequences of $\beta$-actin and TR isoform PCR primers based on chicken mRNA sequences, their associated optimal PCR conditions and the \% similarity of chicken sequences to those of domestic ducks (Anas platyrynchos)

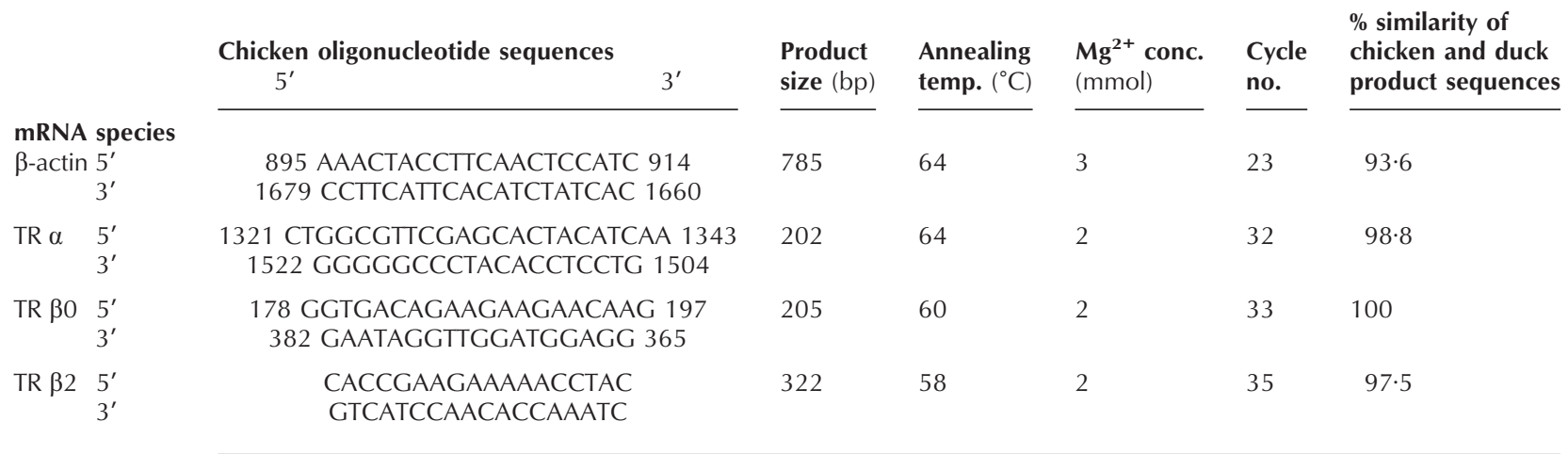

(accession number Y00987), TR $\beta 0$ (M65207) and TR $\beta 2$ (X62642) published by Genbank. Primers for $\beta$-actin (L08165) were designed and used as an internal standard to correct for sample to sample variation in RNA extraction, degradation and reverse transcription. All values for each PCR product for TRs were normalised and expressed as a ratio with respect to the quantity of $\beta$-actin. $\beta$-Actin has been used as an internal standard, or as a representative house-keeping gene, in brain and non-muscle tissues (Gittoes 1997, Slagboom et al. 1990). $\beta$-Actin is not part of the contractile process, so it might be expected to perform equally well as an internal standard in muscle tissues. To check that there was no systematic bias in the expression of $\beta$-actin as a result of the experimental treatment, fluorescence densitometry values for $\beta$-actin expression (arbitrary units) in cardiac, pectoralis and semimembranosus muscles were tested by ANOVA and found to exhibit no significant differences between experimental treatments (Table 1).

Table 2 lists oligonucleotide primer sequences, expected PCR product sizes, $\mathrm{Mg}^{2+}$ concentration, annealing temperatures and number of PCR cycles used for each primer pair. For each primer pair, a sample of the PCR product generated from the duck tissue was sequenced and the result compared with the published chicken sequence, excluding the primer sequences themselves (Table 2). PCR products were purified for sequencing after excision from TAE agarose gels and elution using QIAQuick gel purification kits (Qiagen, Hilden, Germany). Fragment concentration was gauged in relation to a DNA mass ladder (Pharmacia, Uppsala, Sweden). Fifty to one hundred nanograms of the resulting pure fragment was subsequently used per sequencing reaction, with $4 \mu \mathrm{l}$ sequence (Perkin Elmer, Foster City, CA, USA) and 3.2 pmol forward or reverse primer. Electropherograms were analysed using DNAstar software.

\section{Statistics}

Data in the text are presented as means \pm S.E.M. Differences between groups were analysed by ANOVA fol- lowed by Fisher's least significant difference post-hoc test. Where the variance between groups was found to be different, the data were first log transformed before applying the ANOVA. The level of significance was taken as $P<0 \cdot 05$.

\section{Results}

Chicken and duck sequence homology

Galliform birds (gamebirds such as grouse and chickens) had a common ancestor with the Anseriform birds (ducks and geese) around 70 million years ago (Sibley \& Alquist 1990). Despite this, we have demonstrated that there is a very high degree of conservation between the TR isoforms of ducks and chickens. Table 2 shows that the degree of similarity between duck and chicken tissue TR mRNA sequences varies between 97 and $100 \%$, while $\beta$-actin mRNA is around $93 \%$ conserved.

\section{Relative TR $m R N A$ tissue distribution by RT-PCR}

The distributions and relative expressions of $\operatorname{TR} \alpha$, TR $\beta 0$ and TR $\beta 2$ mRNAs in the six tissues sampled from 8 -week-old ducks are shown in Fig. 1. TR $\alpha$ mRNA was expressed in all tissues, but especially abundant expression was observed in the heart and pectoralis muscles. In contrast, TR $\beta 0$ mRNA was less abundant in skeletal and cardiac muscles but strongly expressed in liver, brain and pituitary tissues. TR $\beta 2$ mRNA was even more restricted in distribution, and was strongly expressed only in the pituitary, with mRNA also detectable in cerebral cortex.

\section{Effect of changes in thyroid status on cardiac and locomotor muscles}

Figure 2 shows that treatment with methimazole at both concentrations employed (12 mg or $6 \mathrm{mg} 100 \mathrm{~g}^{-1} \mathrm{BM}$ ) was effective in reducing serum levels of $\mathrm{T}_{4}$ and $\mathrm{T}_{3}$ below 

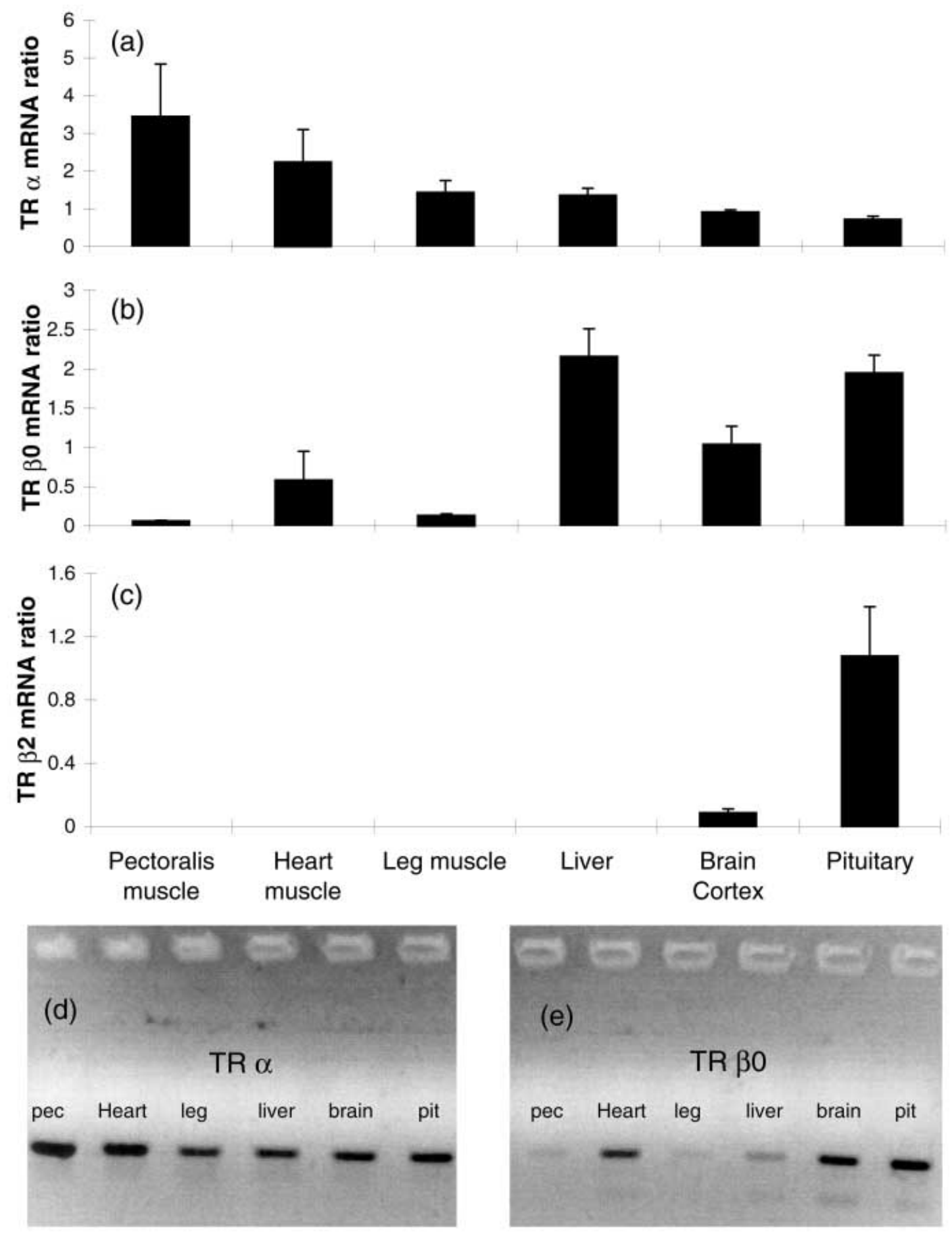

Figure 1 Ratios of (a) TR $\alpha$, (b) TR $\beta 0$ and (c) TR $\beta 2$ isoform mRNA expression normalised with respect to $\beta$-actin mRNA expression in six tissues of 8 -week-old domestic ducklings. Data are presented as means \pm S.E.M. Sections $d$ and e are photographs of $2 \%$ agarose gels showing the fluorescence of RT-PCR products for TR $\alpha$ and TR $\beta 0$ mRNA purified from the same six tissues. Pec, pectoralis muscle; pit, pituitary. 

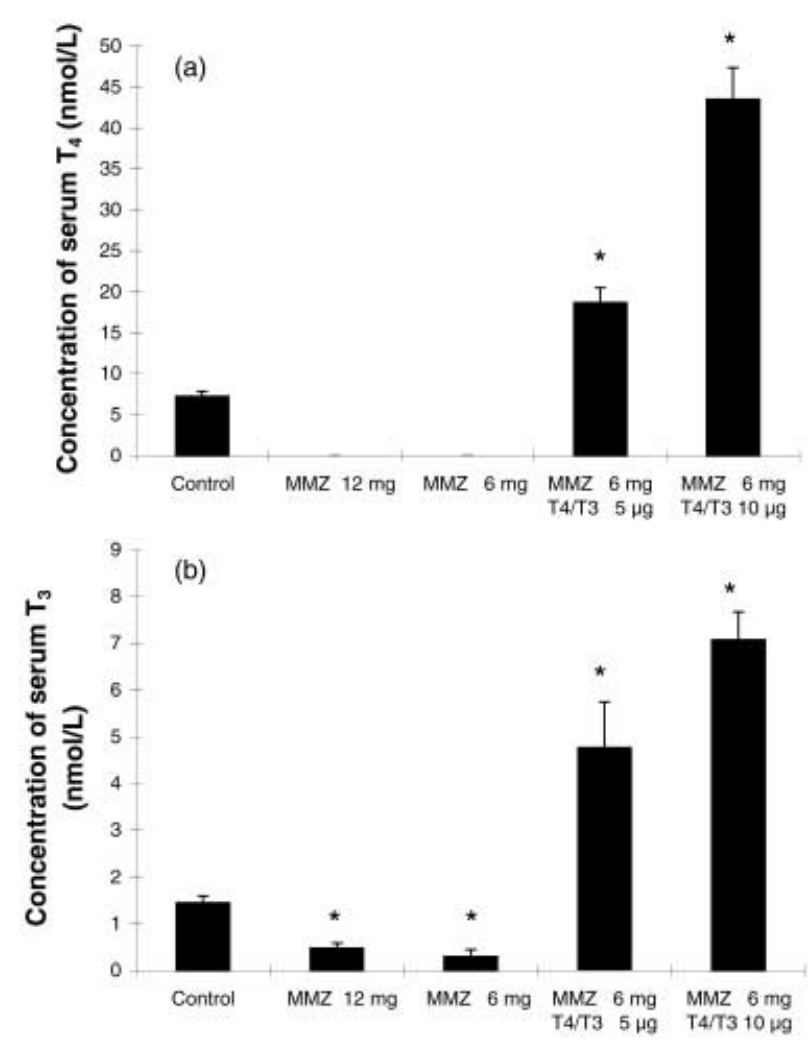

Figure 2 (a) Total $\mathrm{T}_{4}$ and (b) total $\mathrm{T}_{3}$ hormone concentrations in serum from 8-week-old domestic ducklings treated with two con-

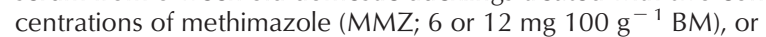
MMZ (6 mg $\left.100 \mathrm{~g}^{-1} \mathrm{BM}\right)$ in combination with two concentrations of both $\mathrm{T}_{4}$ and $\mathrm{T}_{3}$ ( 5 or $10 \mu \mathrm{g} 100 \mathrm{~g}^{-1} \mathrm{BM}$ ). Data are presented as means \pm S.E.M. ${ }^{*} P<0 \cdot 05$.

those in euthyroid control birds (7 and 2 nmol $1^{-1}$ respectively) at 8 weeks of age. Serum $\mathrm{T}_{4}$ was reduced to below the level of assay sensitivity $\left(<5 \mathrm{nmol}^{-1}\right)$, while serum $T_{3}$ concentrations were 1.3 and $1 \mathrm{nmol}^{-1}$ respectively. Treatment with $5 \mu \mathrm{g}$ or $10 \mu \mathrm{g} 100 \mathrm{~g}^{-1} \mathrm{BM}$ of both $\mathrm{T}_{4}$ and $\mathrm{T}_{3}$ in combination with methimazole $(6 \mathrm{mg}$ $100 \mathrm{~g}^{-1} \mathrm{BM}$ ) increased serum $\mathrm{T}_{4}$ levels to three and six times that of euthyroid controls respectively, and increased serum $\mathrm{T}_{3}$ levels to three and five times that of control birds.

Table 3 shows the impact of changes in thyroid status on muscle mass and the maximum activity of CS. The methimazole-treated hypothyroid ducklings had significantly smaller relative masses of both cardiac $(P<0 \cdot 01)$ and pectoralis $(P<0 \cdot 01)$ muscles compared with those of controls. Absolute leg muscle mass was lower in hypothyroid ducklings treated with $6 \mathrm{mg}$ methimazole $100 \mathrm{~g}^{-1} \mathrm{BM}$ $(P<0 \cdot 05)$ in line with the reduction in overall $\mathrm{BM}$, while relative leg muscle mass was not affected. The hyperthyroid ducklings, as a result of treatment with methimazole in combination with both $\mathrm{T}_{4}$ and $\mathrm{T}_{3}$, had cardiac and pectoralis muscle masses similar to those of control birds. Activity of CS was lower by $40 \%(P<0 \cdot 05)$ and $60 \%(P<0.05)$ of control values in the pectoralis and leg muscles, respectively, of hypothyroid ducks, while CS activity of the cardiac muscles was not affected. In hyperthyroid birds, the activity of CS in the cardiac and pectoralis muscles was similar to that of controls birds.

RT-PCR analysis of relative TR $\alpha$ mRNA expression in pectoralis, semimembranosus and cardiac muscles yielded no significant differences between any of the experimental groups (data not shown), while TR $\beta 2$ mRNA was not quantified due to its very restricted tissue distribution. Figure 3 shows the results for RT-PCR analysis of relative TR $\beta 0$ mRNA expression. Hyperthyroidism resulted in a significantly higher TR $\beta 0$ mRNA expression in cardiac $(4 \cdot 2$-fold, $F=7 \cdot 07, P=$ $0.003)$, pectoralis $(3.5$-fold, $F=2 \cdot 05, P<0.05)$ and leg (4.0-fold, $F=9.94, \quad P<0 \cdot 001)$ muscles compared with those of euthyroid controls $(0 \cdot 822 \pm 0 \cdot 297,0 \cdot 098 \pm 0 \cdot 019$ and $0.38 \pm 0.202$ respectively). However, only the leg muscle showed a different response to hypothyroidism, with a significantly lower TR $\beta 0$ mRNA expression in birds treated with $12 \mathrm{mg}$ methimazole $100 \mathrm{~g}^{-1} \mathrm{BM}$ $(0 \cdot 109 \pm 0 \cdot 047, P<0 \cdot 05)$.

\section{Effect of changes in thyroid status on liver $T R m R N A$ and enzyme expression}

Quantitative analysis of relative TR $\alpha$ and TR $\beta 0 \mathrm{mRNA}$ expression in liver samples showed no significant differences between any of the experimental groups (Fig. 4). However, Fig. 4 also shows that the maximum activity of malic enzyme in the liver was significantly lower $(P<0.001)$ in hypothyroid ducks (by 50-60\%) compared with that of the control birds $\left(15 \mu \mathrm{mol} \mathrm{g} \mathrm{g}^{-1} \mathrm{~min}^{-1}\right)$. Hyperthyroid birds had significantly higher values $(P<0.05)$ for malic enzyme (by $25-30 \%)$. In contrast, the maximum activities of malic enzyme in the cardiac and locomotor muscles were relatively low (between 2 and $3 \mu \mathrm{mol} \mathrm{g}^{-1} \mathrm{~min}^{-1}$ ) and were not significantly different between any of the groups (data not shown).

\section{Discussion}

This study has established that the TR isoform mRNAs of 8-week-old ducklings are differentially distributed between different tissues. The general pattern of their expression is similar to that described for mammals (Lazar 1993), in that avian TR $\alpha$ mRNA was ubiquitous in distribution, while TR $\beta 2$ mRNA was strongly expressed only in the pituitary gland. TR $\beta 2$ mRNA expression was also detected in the cerebral cortex of the ducklings, and its expression has been reported in the retinal tissue of chick embryos (Sjöberg et al. 1992). TR $\beta 0$ mRNA 
Table 3 The effects of induced hypo- and hyperthyroidism on morphological characteristics of domestic ducks (Anas platyrynchos) and maximum activity of CS in semimembranosus, pectoralis and cardiac muscles. Data are presented as means \pm S.E.M.

\begin{tabular}{|c|c|c|c|c|c|}
\hline & Control & $\mathbf{M M Z}(12$ mg) & $\mathbf{M M Z}(6$ mg) & $\begin{array}{l}\mathbf{M M Z}+\mathbf{T}_{\mathbf{4}} / \mathbf{T}_{\mathbf{3}} \\
(5 \mu \mathrm{g})\end{array}$ & $\begin{array}{l}\mathbf{M M Z}+\mathbf{T}_{\mathbf{4}} / \mathbf{T}_{\mathbf{3}} \\
(10 \mu \mathrm{g})\end{array}$ \\
\hline \multicolumn{6}{|l|}{ Variable } \\
\hline $\mathrm{BM}(\mathrm{g})$ & $3424 \pm 59$ & $2946 \pm 277$ & $2818 \pm 192^{* *}$ & $3348 \pm 133$ & $3518 \pm 81$ \\
\hline Relative pectoralis mass (\% BM) & $9 \cdot 42 \pm 0 \cdot 4$ & $6 \cdot 66 \pm 0.68^{* *}$ & $6 \cdot 38 \pm 0 \cdot 48^{* *}$ & $9 \cdot 8 \pm 0 \cdot 4$ & $9 \cdot 66 \pm 0 \cdot 28$ \\
\hline Leg muscle mass (g) & $34 \cdot 9 \pm 1 \cdot 8$ & $29 \cdot 4 \pm 2 \cdot 7$ & $28 \cdot 3 \pm 3 \cdot 2^{*}$ & $33 \cdot 3 \pm 0 \cdot 8$ & $37 \cdot 4 \pm 1 \cdot 0$ \\
\hline Relative leg mass (\% BM) & $1 \cdot 02 \pm 0.06$ & $1 \cdot 00 \pm 0 \cdot 02$ & $1 \cdot 04 \pm 0 \cdot 04$ & $1 \cdot 00 \pm 0 \cdot 04$ & $1.06 \pm 0.02$ \\
\hline 9th primary feather length $(\mathrm{mm})$ & $136 \pm 3 \cdot 1$ & $75 \cdot 5 \pm 23 \cdot 4^{*}$ & $46 \cdot 4 \pm 1 \cdot 2^{* *}$ & $138 \cdot 1 \pm 4 \cdot 0$ & $130 \cdot 8 \pm 1 \cdot 7$ \\
\hline Tibiotarsus bone length $(\mathrm{mm})$ & $85 \cdot 1 \pm 0 \cdot 3$ & $81 \cdot 6 \pm 1 \cdot 2^{*}$ & $81 \cdot 3 \pm 1 \cdot 2^{*}$ & $84 \cdot 9 \pm 0 \cdot 8$ & $85 \cdot 7 \pm 1 \cdot 1$ \\
\hline Radius bone length (mm) & $119 \pm 1 \cdot 0$ & $104 \pm 4 \cdot 8^{* *}$ & $99 \cdot 9 \pm 5 \cdot 9^{* *}$ & $116 \pm 1 \cdot 3$ & $117 \pm 1 \cdot 2$ \\
\hline Sternum length (mm) & $145 \pm 1 \cdot 6$ & $114 \pm 5 \cdot 3^{* *}$ & $110 \pm 4 \cdot 0^{* *}$ & $143 \pm 4 \cdot 6$ & $146 \pm 1.9$ \\
\hline Head length (mm) & $145 \pm 0 \cdot 7$ & $127 \pm 2 \cdot 8^{* *}$ & $125 \pm 4 \cdot 1^{* *}$ & $143 \pm 1.9$ & $143 \pm 1 \cdot 8$ \\
\hline \multicolumn{4}{|l|}{ Mass-specific activity of CS in } & $36 \cdot 9 \pm 2 \cdot 2$ & $30 \cdot 0 \pm 4 \cdot 0$ \\
\hline semimembranosus muscle ( $\mu \mathrm{mol} / \mathrm{g}$ per min) & $24 \cdot 1 \pm 2 \cdot 4$ & $17 \cdot 0 \pm 1 \cdot 6$ & $13 \cdot 0 \pm 1 \cdot 9^{* *}$ & $30 \cdot 6 \pm 0 \cdot 8$ & $28 \cdot 6 \pm 2 \cdot 5$ \\
\hline
\end{tabular}

$M M Z$, methimazole.

${ }^{*} P<0 \cdot 05,{ }^{* *} P<0.001$.

expression showed marked differences in abundance between tissue types but was relatively more abundant in cardiac than striated muscle tissue. Striated muscle appeared to express primarily TR $\alpha$ mRNA. A similar pattern of distribution for TR $\alpha$ and $\beta 1$ mRNA expression in cardiac and striated muscle tissue has recently been reported for the rat and the human (Haddad et al. 1998, Shahrara et al. 1999). TR $\beta 0$ mRNA expression was significantly modulated by changes in thyroid status, unlike TR $\alpha$ mRNA. In addition, the pattern of TR $\beta 0$ mRNA modulation by thyroid hormones was tissue specific.

The findings of this study demonstrate that there is not always a close association between the effect of changes in thyroid status on TR isoform mRNA expression and effects on tissue phenotype, such as tissue mass or the maximum activities of specific metabolic enzymes. Thus, these results support the hypothesis that mechanistic interpretations of target gene regulation by thyroid hormone receptor binding are likely to be tissue specific (Lin et al. 1997).

The major site for lipogenesis is the liver, and samples from the 8-week-old ducklings in the present study demonstrated a direct relationship in vivo between hypoand hyperthyroidism and a subsequent decrease or increase, respectively, in the lipogenic activity of hepatic malic enzyme. However, the expression of TR $\alpha$ and TR $\beta 0$ isoform mRNAs in the liver of the ducks was not affected by thyroid status. Thus, the marked positive thyroid hormone regulation of the activity of hepatic malic enzyme did not require changes in the level of expression of the TR $\alpha$ and TR $\beta 0$ isoform mRNAs. Assuming that there is little post-transcriptional regulation as a result of changes in thyroid status, a reduction in serum thyroid hormone concentration would result in a lower rate of ligand/receptor binding. This reduction in receptor occupancy could decrease the direct stimulation of transcription of the target gene, and may also result in increased ligand-independent repression of transcription (Chen \& Evans 1995, Horlein et al. 1995, Wondisford 1996).

The activity of malic enzyme in the locomotor and cardiac muscles of the ducklings was not affected by thyroid status. This result is similar to that reported in neonatal rats where hepatic malic enzyme activity was positively regulated by thyroid status but brain malic enzyme activity was unaffected (Sood et al. 1996). Thus, our results suggest that tissue-specific factors in avian muscle impair thyroid hormone-induced expression of malic enzyme.

The effects of changes in thyroid status on the activity of CS and TR mRNA isoform transcription are more complex in the cardiac and locomotor muscles than in the liver. As a consequence of the exposure to a hyperthyroid state, TR $\alpha$ mRNA abundance, muscle mass measurements and CS enzyme activities were similar in all three muscles studied, while TR $\beta 0$ mRNA expression was significantly higher in these tissues. In the leg muscle, TR B0 mRNA expression was lower during hypothyroidism along with a slightly lower activity of CS and absolute muscle mass, although relative leg muscle mass was unaltered. In the cardiac and pectoralis muscles, exposure 

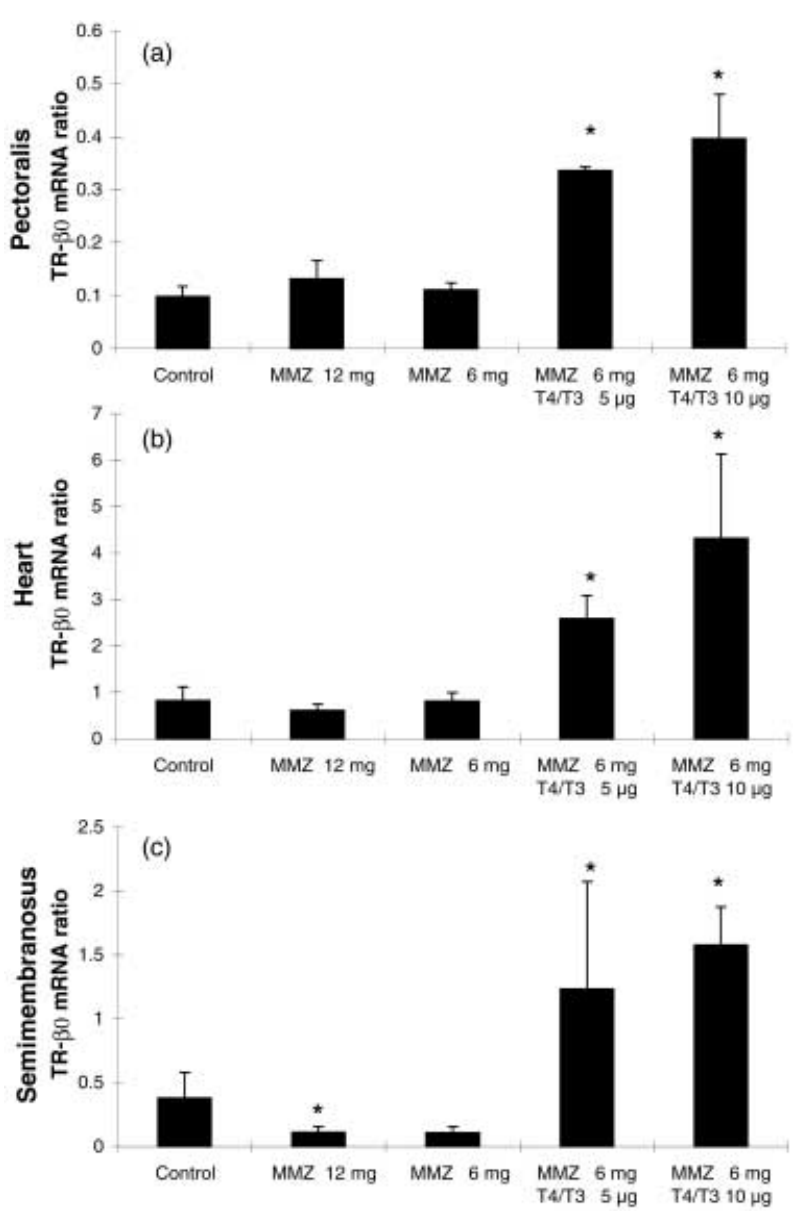

Figure 3 Ratio of TR $\beta 0$ mRNA isoform expression normalised with respect to $\beta$-actin mRNA expression in (a) pectoralis, (b) cardiac and (c) semimembranosus muscle tissue from 8-weekold domestic ducklings treated with two concentrations of methimazole $(\mathrm{MMZ})$, or $\mathrm{MMZ}$ in combination with both $\mathrm{T}_{4}$ and $\mathrm{T}_{3}$. For details see legend to Fig. 2. Data are presented as means \pm S.E.M. ${ }^{*} P<0 \cdot 05$.

to hypothyroidism did not affect TR $\beta 0$ mRNA expression while cardiac and pectoralis mass and pectoralis CS activity were lower.

The finding that hyperthyroidism in the domestic duck did not lead to an increase in cardiac and locomotor muscle mass, or aerobic capacity, is consistent with previous findings in the barnacle goose (Deaton et al. 1997, 1998). This suggests that these tissues are already developing at a maximal rate in euthyroid birds with regard to stimulation of muscle growth by thyroid hormones. Conversely, induction of hypothyroidism significantly reduced the aerobic capacity of the locomotor muscles, and this action was effected independently of any pretranslational regulation of TR isoform mRNAs. It is possible that the alterations in muscle mass and mass-specific CS enzyme activity, as a result of changes in thyroid status, were
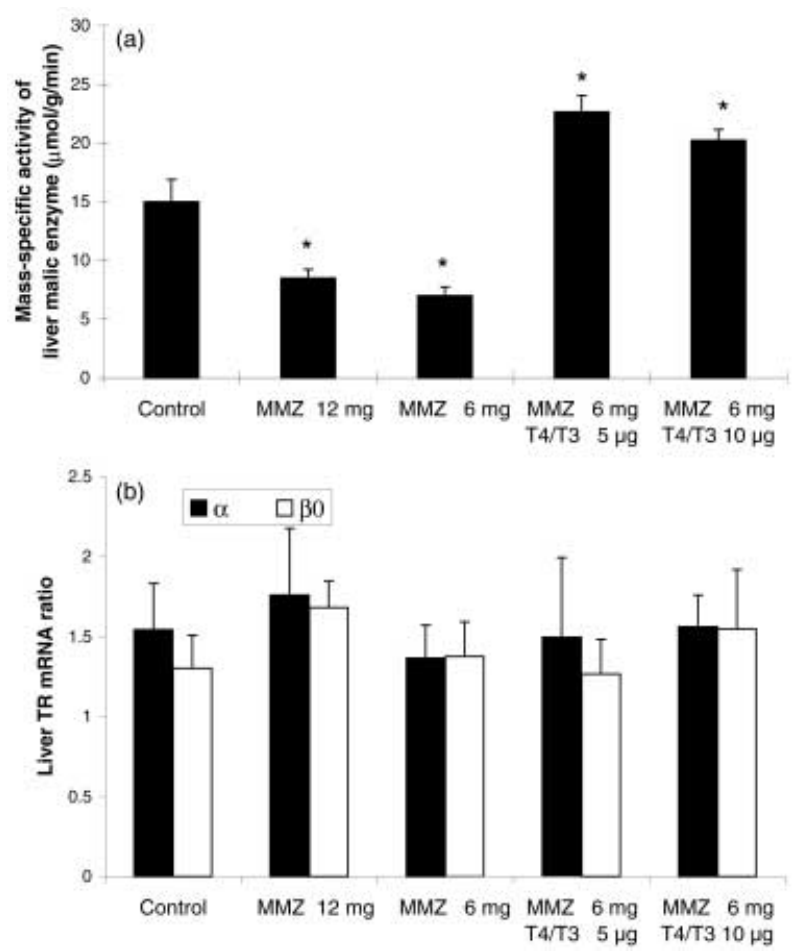

Figure 4 (a) Maximum mass-specific activity of malic enzyme $\left(\mu \mathrm{mol} \mathrm{g} \min ^{-1}\right)$ and (b) the ratio of TR $\alpha$ and TR $\beta 0$ mRNA isoform expression normalised with respect to $\beta$-actin mRNA expression in liver from 8-week-old domestic ducklings treated with two concentrations of methimazole (MMZ), or MMZ in combination with both $T_{4}$ and $T_{3}$. For details see legend to Fig. 2. Data are presented as means \pm S.E.M. ${ }^{*} P<0 \cdot 05$.

influenced by an independent effect of hyper- and hypothyroidism on the nutritional intake of the animals (cf. Harrison et al. 1996). In addition, deiodinase enzymes are expressed in muscle tissue (St Germain \& Galton 1997, Hosoi et al. 1999) and their possible influence could be considered in further experiments.

The present study has highlighted the tissue-specific nature of the pretranslational regulation of TR mRNAs and associated target proteins to changes in the thyroid status of birds. In particular, modulation of the activity of thyroid-sensitive enzymes, such as malic enzyme and CS, are not necessarily associated with changes in TR $\alpha$ and TR $\beta 0$ mRNA expression. Future work should focus on the effect of thyroid status on the regulation of TR isoform translation and on changes in associated nuclear receptor species and their co-activators and co-repressors in avian tissues, since complex interactions between these proteins are likely to determine the transcriptional regulatory effects of thyroid hormones.

\section{Acknowledgements}

This work was supported primarily by an award from the Leverhulme Trust. Additional support was received from 
the MRC, Smith and Nephew Foundation and the West Midlands Regional Health Authority.

\section{References}

Bishop CM, Butler PJ, Egginton S, El Haj AJ \& Gabrielsen GW 1995 Development of metabolic enzyme activity in locomotor and cardiac muscles of the migratory barnacle goose. American Journal of Physiology 269 R64-R72.

Bishop CM, Butler PJ, El Haj AJ, Egginton S \& Loonen MJJE 1996 The morphological development of the locomotor and cardiac muscles of the migratory barnacle goose (Branta leucopsis). Journal of Zoology 239 1-15.

Bishop CM, Butler PJ, Egginton S \& El Haj AJ 1998 Comparative development of captive and migratory populations of the barnacle goose. Physiological Zoology 71 198-207.

Chen JD \& Evans RM 1995 A transcriptional co-repressor that interacts with nuclear hormone receptors. Nature 377 454-457.

Deaton KE, Bishop CM \& Butler PJ 1996 Variation in the activity of citrate synthase within the pectoralis of the barnacle goose, Branta leucopsis. Journal of Avian Biology 27 354-356.

Deaton KE, Bishop CM \& Butler PJ 1997 The effect of thyroid hormones on the aerobic development of locomotor and cardiac muscles in the barnacle goose. Journal of Comparative Physiology $B$ 167 319-327.

Deaton KE, Bishop CM \& Butler PJ 1998 Tissue-specific effects of hypothyroidism on post-hatch muscle development in the barnacle goose. Journal of Experimental Biology 201 827-836.

Diamant S, Gorin E \& Shafrir E 1972 Enzyme activities related to fatty-acid synthesis in liver and adipose tissue of rats treated with triiodothyronine. European Journal of Biochemistry 26 553-559.

Dussault JH \& Ruel J 1987 Thyroid hormones and brain development. Annual Review of Physiology 49 321-334.

Everts ME 1996 Effects of thyroid hormones on contractility and cation transport in skeletal muscle. Acta Physiologica Scandinavica 156 325-333.

Forrest D, Sjöberg M \& Vennström B 1990 Contrasting developmental and tissue-specific expression of $\alpha$ and $\beta$ thyroid hormone receptor genes. EMBO Journal 9 1519-1528.

Forrest D, Hallböök F, Persson H \& Vennström B 1991 Distinct function for thyroid hormone receptors alpha and beta in brain development indicated by differential expression of receptor genes. EMBO Journal 10 269-275.

Gittoes NJL, McCabe CJ, Verhaeg J, Sheppard MC \& Franklyn JA 1997 Thyroid hormone and estrogen receptor expression in normal pituitary and nonfunctioning tumors of the anterior pituitary. Journal of Clinical Endocrinology and Metabolism 82 1960-1967.

Gittoes NJL, McCabe CJ, Verhaeg J, Sheppard MC \& Franklyn JA 1998 Retinoid X receptor expression in the normal pituitary and clinically 'non-functioning' pituitary tumours. Clinical Endocrinology 48 425-433.

Haddad F, Qin AX, McCue SA \& Baldwin KM 1998 Thyroid receptor plasticity in striated muscle types: effects of altered thyroid state. American Journal of Physiology 274 E1018-E1026.

Harrison AP, Tivey DR, Clausen T, Duchamp C \& Dauncey MJ 1996 Role of thyroid hormones in early postnatal development of skeletal muscle and its implications for undernutrition. British Journal of Nutrition 76 841-855.
Hodnett DW, Fantozzi DA, Thurmond DC, Klautky SA, MacPhee KG, Estrem ST, Xu G \& Goodridge AG 1996 The chicken malic enzyme gene: Structural organization and identification of triiodothyronine response elements in the $5^{\prime}$-flanking DNA. Archives of Biochemistry and Biophysics 334 309-324.

Horlein AJ, Naar AM \& Heinzel T 1995 Ligand-independent repression by the thyroid hormone receptor mediated by a nuclear receptor co-repressor. Nature 377 397-404.

Horton DHA 1928 The growth of white Pekin ducklings. Poultry Science 8 163-167.

Hosoi Y, Murakami M, Mizuma H, Ogiwara T, Imamura M \& Mori M 1999 Expression and regulation of type II iodothyronine deiodinase in cultured human skeletal muscle cells. Journal of Clinical Endocrinology and Metabolism 84 3293-3300.

Lazar MA 1993 Thyroid hormone receptors: multiple forms, multiple possibilities. Endocrine Reviews 14 184-193.

Lin K-h, Chen S-l, Zhu X-G, Shieh H-y, McPhie P \& Cheng S-y 1997 The gene regulating activity of thyroid hormone nuclear receptors is modulated by cell-type specific factors. Biochemical and Biophysical Research Communications 238 280-284.

Muñoz A \& Bernal J 1997 Biological activities of thyroid hormone receptors. European Journal of Endocrinology 137 433-445.

Oppenheimer JH \& Schwartz HL 1997 Molecular basis of thyroid hormone-dependent brain development. Endocrine Reviews 18 462-475.

Petty KJ, Desvergne B, Mitsuhashi T \& Nikodem VM 1990 Identification of a thyroid-hormone response element in the malic enzyme gene. Journal of Biological Chemistry 265 7395-7400.

St Germain DL \& Galton VA 1997 The deiodinase family of selenoproteins. Thyroid 7 655-668.

Sedinger JS 1986 Growth and development of Canada goose goslings. Condor 88 169-180.

Shahrara S, Drvota V \& Sylven C 1999 Organ specific expression of thyroid hormone receptor mRNA and protein in different human tissues. Biological and Pharmaceutical Bulletin 22 1027-1033.

Sibley CG \& Alquist JE 1990 Phylogeny and Classification of Birds: A Study in Molecular Evolution, pp 1008. New Haven: Yale University Press.

Sjöberg M, Vennström B \& Forrest D 1992 Thyroid hormone receptors in chick retinal development: differential expression of mRNAs for alpha and $\mathrm{N}$-terminal variant beta receptors. Development 114 39-47.

Slagboom PE, De Leeuw WJF \& Vij GJ 1990 Messenger-RNA levels and methylation patterns of GAPDH and beta-actin genes in ratliver, spleen and brain in relation to aging. Mechanisms of Aging and Development 53 243-257.

Sood A, Schwartz HL \& Oppenheimer JH 1996 Tissue-specific regulation of malic enzyme by thyroid hormone in the neonatal rat. Biochemical and Biophysical Research Communications 222 287-291.

Wondisford FE 1996 Editorial: Thyroid hormone action beyond the receptor. Journal of Clinical Endocrinology and Metabolism $\mathbf{8 1}$ 4194-4195.

Received 7 October 1999

Revised manuscript received 25 January 2000

Accepted 16 February 2000 